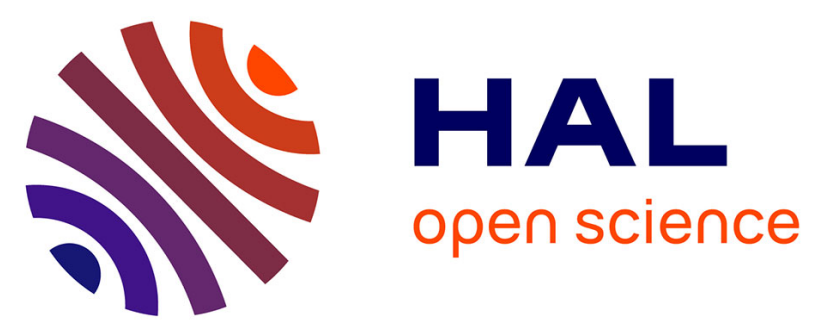

\title{
Highly Efficient Asymmetric Hydrogenation of Alkyl Aryl Ketones Catalyzed by Iridium Complexes with Chiral Planar Ferrocenyl Phosphino-Thioether Ligands
}

\author{
Erwan Le Roux, Raluca Malacea-Kabbara, Eric Manoury, Rinaldo Poli, Luca
}

Gonsalvi, Maurizio Peruzzini

\section{To cite this version:}

Erwan Le Roux, Raluca Malacea-Kabbara, Eric Manoury, Rinaldo Poli, Luca Gonsalvi, et al.. Highly Efficient Asymmetric Hydrogenation of Alkyl Aryl Ketones Catalyzed by Iridium Complexes with Chiral Planar Ferrocenyl Phosphino-Thioether Ligands. Advanced Synthesis and Catalysis, 2007, 349 (3), pp.309-313. 10.1002/adsc.200600350 . hal-03194673

\section{HAL Id: hal-03194673 https://hal.science/hal-03194673}

Submitted on 9 Apr 2021

HAL is a multi-disciplinary open access archive for the deposit and dissemination of scientific research documents, whether they are published or not. The documents may come from teaching and research institutions in France or abroad, or from public or private research centers.
L'archive ouverte pluridisciplinaire HAL, est destinée au dépôt et à la diffusion de documents scientifiques de niveau recherche, publiés ou non, émanant des établissements d'enseignement et de recherche français ou étrangers, des laboratoires publics ou privés. 


\title{
Highly efficient asymmetric hydrogenation of alkyl aryl ketones catalyzed by iridium complexes with chiral planar ferrocenyl phosphino-thioether ligands
}

Erwan Le Roux, ${ }^{a}$ Raluca Malacea, ${ }^{\mathrm{b}}$ Eric Manoury, ${ }^{\mathrm{b} *}$ Rinaldo Poli, ${ }^{\mathrm{b}}$ Luca Gonsalvi, ${ }^{\mathrm{a}}$ Maurizio Peruzzini $^{\mathrm{a} *}$

a Consiglio Nazionale delle Ricerche, Istituto di Chimica dei Composti Organometallici(ICCOM-CNR), Via Madonna del Piano, 50019 Sesto Fiorentino (Firenze), Italy; e-mail: mperuzzini@iccom.cnr.it

b Centre National de la Recherche Scientifique, Laboratoire de Chimie de Coordination (CNRS-LCC),205, route de Narbonne, 31077 Toulouse Cedex 4,France; e-mail: manoury@lcc-toulouse.fr

\begin{abstract}
Iridium complexes of planar-chiral ferrocenyl phosphine-thioether ligands were tested in the hydrogenation of simple ketones. Conditions optimization led to a highly active catalytic system with turnover numbers up to 915 and turnover frequencies up to ca. $250 \mathrm{~h}^{-1}$. Furthermore, very high enantioselectivities (up to $>99 \%$ ) together with complete conversions were obtained for the asymmetric hydrogenation of various acetophenones at $10^{\circ} \mathrm{C}$.
\end{abstract}

Keywords: alkyl aryl ketones; asymmetric catalysis; ferrocene ligands; hydrogenation; iridium; P,S ligands

The development of new asymmetric catalytic systems is still a major challenge because of its importance in synthetic organic chemistry and fine chemicals manufacturing. ${ }^{[1]}$ For instance, enantiomerically pure secondary alcohols, which are very valuable synthetic intermediates for pharmaceuticals or materials, can often be obtained by asymmetric ketone hydrogenation. The catalytic hydrogenation of unfunctionalized ketones, i.e. lacking 
additional heteroatoms for secondary interactions of the substrate with the metal center, have long been a major goal ${ }^{[2-3]}$ until Noyori et al. introduced new ruthenium-based $\left[(\text { diphosphine }) \mathrm{RuCl}_{2} \text { (diamine) }\right]^{[4]}$ complexes which proved outstanding in terms of both activities and enantioselectivities. Though many ruthenium-based catalytic systems have been developed during the last decade, ${ }^{[5]}$ the use of other metals in this reaction have been rather rarely described. ${ }^{[6-8]}$ Herein, we report a highly active and highly enantioselective catalytic system for the hydrogenation of various substituted acetophenones, based on Ir complexes of ferrocenyl phosphine-thioether ligands. We have recently developed syntheses of new chiral ferrocenyl P,S ligands in both racemic and enantiomerically pure form ( $R$ or $S$ configuration), and briefly reported on their application to asymmetric catalysis, namely in palladiumcatalyzed allylic substitution. ${ }^{[9-10]}$ We have also described iridium complexes $\mathbf{2}-\mathbf{R}(\mathrm{R}=\mathrm{Ph}, \mathrm{Et}$, $t \mathrm{Bu}$, see Scheme 1), obtained in high yields (85\%-90\%) and with complete diastereoselectivity via the addition of the bidentate ligands $\mathbf{1 - R}$ to $[\operatorname{Ir}(\operatorname{cod}) \mathrm{Cl}]_{2 .}{ }^{[11]}$ The coordination number of $\mathbf{2}-\mathbf{R}$ is controlled by the size of $\mathrm{R}$ (5-coordinate for the smaller $\mathrm{Ph}$ and Et, square planar 4-coordinate for the bulkier $t \mathrm{Bu}$ ), both in the solid state and in solution, while the absolute configuration at the coordinated sulphur atom is in turn controlled by the ferrocene planar chirality (only one diastereoisomer is obtained). ${ }^{[1 \mathrm{a}]}$ By using the same procedure, we have now prepared the benzyl analogue (2-Bz) starting from ligand $\mathbf{1 - B z}{ }^{[9]}$ and $[\operatorname{Ir}(\operatorname{cod}) \mathrm{Cl}]_{2}$. NMR data for $\mathbf{2 - B z}$ are similar to those of 2-Et and 2-Ph. In particular, the ${ }^{31} \mathbf{P}$ signal (-9 ppm) is close to the corresponding signals of 2-Et and 2-Ph (respectively -3.1 ppm and $-4.2 \mathrm{ppm}$ ) but not to the signal of $2-\mathbf{t} \mathbf{B u}(15.7 \mathrm{ppm})$. The ${ }^{1} \mathrm{H}$ NMR data ( $\delta$ and $\mathrm{J}_{\mathrm{HH}}$ ) of the two diastereotopic protons of the methylene group between the ferrocene moiety and the sulphur atom are also much more affected by coordination than in the case of 2-tBu. This suggests that the sulphur atom is coordinated to the iridium center and therefore that $\mathbf{2}-\mathbf{B z}$ is pentacoordinated like 2-Et and 2-Ph.

In order to assess the efficiency of these complexes in ketone hydrogenation, the experimental conditions were first optimized for the hydrogenation of acetophenone as a model substrate with the racemic catalysts $\mathbf{2}-\mathbf{R}$, followed by the asymmetric hydrogenation of various substituted alkyl aryl ketones with the enantiomerically pure complexes. The asymmetric hydrogenation of simple ketones is commonly carried out in alcoholic solvents, typically isopropanol, in the presence of a base. ${ }^{[4-8]}$ Therefore, the hydrogenation of acetophenone was first studied in isopropanol (see table 1). In the absence of a base, 2-Et showed no catalytic activity (run 1). The addition of KI had no effect on the reaction rate ${ }^{[12]}$ (run 2), whereas $\mathrm{I}_{2}$ had a positive but limited effect (run 3). ${ }^{[13]}$ On the other hand, the addition 
of a strong base ( $\mathrm{NaOMe}, \mathrm{KO} t \mathrm{Bu}$ or $\mathrm{KOH} ; 5$ equivalents) efficiently promoted catalysis (runs 4-6). The weaker base $\mathrm{NEt}_{3}$ had no significant effect (run 7), contrary to former observations by Dahlenburg and Götz for related iridium-based catalytic systems. ${ }^{[8 \mathrm{~d}]}$ The iridium/substrate ratio could be decreased to $1 / 1500$ while maintaining significant conversions after $5 \mathrm{~h}(61 \%$ corresponding to a turnover number of 915; run 8). The optimised conditions for 2-Et were finally applied to the other 2-R complexes. All proved to be efficient catalysts, with complete conversion after $5 \mathrm{~h}$ in all cases (runs 9-11). These activities appear to compare quite favourably with those reported for other Ir complexes under similar conditions. ${ }^{[8]}$ The reason for this difference may be related to a greater hemilability of these P,S ligands, ${ }^{[11 \mathrm{~b}]}$ relative to the other chelating ligands used so far.

The solvent influence on the catalytic activity has also been investigated (see table 2). The runs in alcoholic solvents were stopped after $2 \mathrm{~h}$ in order to better compare the catalytic activities. The catalytic activity depends on the alcohol nature (runs 12-16). In particular, the reactivity dropped dramatically in $t$-butanol (cf. runs 15 and 16 for the 2-Et catalyst), in contrast again with the system developed by Dahlenburg and Götz. ${ }^{[8 \mathrm{~d}]}$ This observation raised the question of the intervention of a transfer hydrogenation pathway, with the alcoholic solvent as the hydride source. However, the reaction could be efficiently carried out in toluene, which can not be a hydride source (runs 18 and 19), ruling out this mechanism under these conditions. Furthermore, the activity in isopropanol dropped dramatically when the reaction was carried out under reduced $\mathrm{H}_{2}$ pressure ( 2 bars, run 17). These two independent observations strongly support the hydrogenation mechanism in alcoholic solvents. Acetophenone could also be hydrogenated efficiently in acetonitrile but not in dichloromethane or THF (runs 20-23). The replacement of $\mathrm{NaOMe}$ with $\mathrm{KO} t \mathrm{Bu}$ increased significantly the activity of 2-Et in toluene, probably because of the higher solubility of the latter base. In MeCN, where both bases are completely soluble, the observed activity is comparable.

The asymmetric hydrogenation using enantiomerically pure $(\boldsymbol{S})-\mathbf{2}-\mathbf{R}$ has been studied under the optimised conditions (i.e. those of table 2, run14). In contrast with the catalytic activities, the enantioselectivities for the acetophenone hydrogenation strongly depend on the R substituent on sulphur, going from $43 \%$ with $(\boldsymbol{S})-\mathbf{2}-\mathbf{P h}$ to $77 \%$ with $(\boldsymbol{S})-\mathbf{2}-\mathbf{B z}$ (table 3, runs 24-27). For substituted acetophenones, enantioselectivities depend also strongly on the R substituent, especially for 2-substituted compounds where, with the more crowded complexes $(\boldsymbol{S})$-2-Ph and $(\boldsymbol{S})-\mathbf{2}-\mathbf{t} \mathbf{B u}$, low enantioselectivities were observed (table 3, runs 2930 and 33-34). However, good levels of enantioselectivities (over 70\%) were observed for the 
3 and 4-substituted acetophenones (runs 36-51). For each substrate, complex (S)-2-Bz gives the best enantioselectivities ( $c f$. runs 27, 31, 35, 39, 43, 47 and 51). The two best ligands in terms of enantioselectivity for the acetophenone hydrogenation (i.e. $(\boldsymbol{S})$-1-Et and $(\boldsymbol{S})-\mathbf{1}-\mathbf{B z})$ were selected for further studies at lower temperature $\left(10^{\circ} \mathrm{C}\right.$, see table 4$)$. This resulted in much higher enantioselectivities (up to $>99 \%$ for 4 -fluoroacetophenone, table 4, runs 52-57), while the catalytic activities remained acceptably high. This outstanding increase is much greater than expected on the basis of a simple Arrhenius relationship for a mononuclear catalyst. It is therefore likely that several catalytically active species are involved. This hypothesis is in agreement with a preliminary investigation of the ee of the product as a function of enantiomeric purity of the catalyst, which shows negative non-linear effect. ${ }^{[14]}$ This aspect of catalytic process is under further investigation.

In conclusion, we have shown that iridium complexes with planar chiral P,S ligands are effective catalysts for the asymmetric hydrogenation of various alkyl aryl ketones with high activities (TOF up to ca. $250 \mathrm{~h}^{-1}$ ) and ee's up to $>99 \%$ with conversions up to $>99 \%$ ). To the best of our knowledge, these activities and enantioselectivities are the best ones reported so far for the iridium-catalyzed hydrogenation of ketones. Future work will focus on investigating the reaction mechanism and on expanding the substrate scope. Only four $(\boldsymbol{S})$-1$\mathbf{R}$ ligands have been used in this study, but a variety of analogues can be easily synthesised, ${ }^{[9 a]}$ opening the way for searching the best complex for each substrate. Therefore, we hope that the fine tuning of the complex stereoelectronic properties, in particular by modification of the $\mathrm{R}$ group, will lead to a more efficient asymmetric hydrogenation of a large variety of simple ketones.

\section{Experimental Section}

General: All reactions were carried out under dry argon by using Schlenk glassware and vacuum line techniques. Commercial samples were used as received. Solvents were freshly distilled from standard drying agents. ${ }^{1} \mathrm{H},{ }^{13} \mathrm{C}\left\{{ }^{1} \mathrm{H},{ }^{31} \mathrm{P}\right\}$ and ${ }^{31} \mathrm{P}\left\{{ }^{1} \mathrm{H}\right\}$ NMR spectra were recorded on the Bruker Avance 500 instrument operating at 500, 200, and $125 \mathrm{MHz}$ respectively. Chemical shifts are reported in parts per million (ppm) relative to $\mathrm{Me}_{4} \mathrm{Si}\left({ }^{1} \mathrm{H}\right.$ and $\left.{ }^{13} \mathrm{C}\right)$ or $85 \% \mathrm{H}_{3} \mathrm{PO}_{4}\left({ }^{31} \mathrm{P}\right)$. Mass spectra were obtained on a Nermag R10-10 instrument 
(DCI, FAB) and on a Applied Biosystem API 365 instrument (APCI). Optical rotations were measured with a Perkin Elmer 241 polarimeter.

Synthesis of complex 2-Bz: Complex 2-Bz was synthesised following the published procedure $^{[11 \mathrm{a}]}$ from ligand 1-Bz. ${ }^{[9]}$

${ }^{1} \mathrm{H}$ NMR (500 MHz, $\left.\mathrm{CDCl}_{3}\right) \delta(\mathrm{ppm}): 8.45$ (br s, 2H, Ar); 7.64-7.60 (m, 3H, Ar); 7.43-7.38 (m, 5H, Ar); 7.27-7.22 (m, 3H, Ar); 7.03-6.99 (m, 2H, Ar); 4.85 (br d (AB syst.), $\mathrm{J}_{\mathrm{HH}}=12 \mathrm{~Hz}$, $\left.1 \mathrm{H}, \underline{\mathrm{CH}}_{2}-\mathrm{Cp}\right) ; 4.24\left(\mathrm{dd}, \mathrm{J}_{\mathrm{HH}}=2.2 \mathrm{~Hz}, \mathrm{~J}_{\mathrm{HH}}=1.5 \mathrm{~Hz}, 1 \mathrm{H}\right.$, subst $\left.\mathrm{Cp}\right) ; 4.14\left(\mathrm{t}, \mathrm{J}_{\mathrm{HH}}=2.5 \mathrm{~Hz}, 1 \mathrm{H}\right.$, subst Cp); 4.12 (d (AB syst.), $\left.\mathrm{J}_{\mathrm{HH}}=13,2 \mathrm{~Hz}, 1 \mathrm{H}, \mathrm{C}_{2}-\mathrm{Ph}\right) ; 3.95$ (m, 1H, subst Cp); 3.94 (d (AB syst.), $\left.\mathrm{J}_{\mathrm{HH}}=13.2 \mathrm{~Hz}, 1 \mathrm{H}, \mathrm{C}_{2}-\mathrm{Ph}\right) ; 3.65(\mathrm{~s}, 5 \mathrm{H}, \mathrm{Cp}) ; 3.62-3.56$ (m, 2H, CH/COD); 3.563.50 (m, 2H, CH/COD); 3.32 (br d (AB syst.), $\mathrm{J}_{\mathrm{HH}}=12 \mathrm{~Hz}, 1 \mathrm{H}, \mathrm{C}_{2}-\mathrm{Cp}$ ); 2.81-2.69 (m, 2H, $\mathrm{CH}_{2} / \mathrm{COD}$ ); 2.18-2.03 (m, 4H, CH $\left./ \mathrm{COD}\right) ; 1.47-1.36$ (m, 2H, $\left.\mathrm{CH}_{2} / \mathrm{COD}\right) .{ }^{13} \mathrm{C}\left\{{ }^{1} \mathrm{H}\right\} \mathrm{RMN}(500$ $\mathrm{MHz}_{\mathrm{CDCl}}$ ) 135.6 (d, $\left.\mathrm{J}_{\mathrm{CP}}=14.3 \mathrm{~Hz}, \mathrm{Ar}\right) ; 135.3$ (s, quat $\mathrm{Ar}$ ); 135.2 (d, $\mathrm{J}_{\mathrm{CP}}=45 \mathrm{~Hz}$, quat $\mathrm{Ar}$ ); $133.9\left(\mathrm{~d}, \mathrm{~J}_{\mathrm{CP}}=51.9 \mathrm{~Hz}\right.$, quat Ar); $131.7\left(\mathrm{~d}, \mathrm{~J}_{\mathrm{CP}}=8.5 \mathrm{~Hz}, \mathrm{Ar}\right) ; 130.6\left(\mathrm{~d}, \mathrm{~J}_{\mathrm{CP}}=3 \mathrm{~Hz}, \mathrm{Ar}\right) ; 129.6$ (s, Ar); 128.9 (s, Ar); 128.8 (s, Ar); 128.0 (s, Ar); 127.8 (d, J $\left.\mathrm{J}_{\mathrm{CP}}=10.4 \mathrm{~Hz}, \operatorname{Ar}\right) ; 127.1$ (d, J $\mathrm{J}_{\mathrm{CP}}=$ $8.9 \mathrm{~Hz}, \operatorname{Ar}) ; 87.8\left(\mathrm{~d}, \mathrm{~J}_{\mathrm{CP}}=18.8 \mathrm{~Hz}\right.$, quat $\left.\mathrm{Cp}\right) ; 72.5$ (d, $\mathrm{J}_{\mathrm{CP}}=7.0 \mathrm{~Hz}$, subst Cp); 72.4 (s, subst $\mathrm{Cp}) ; 70.7\left(\mathrm{~d}, \mathrm{~J}_{\mathrm{CP}}=44.5 \mathrm{~Hz}\right.$, quat $\left.\mathrm{Cp}\right) ; 70.5$ (s, Cp); 68.8 (d, $\mathrm{J}_{\mathrm{CP}}=4.6 \mathrm{~Hz}$, subst Cp); 66.12 (s, $\mathrm{CH} / \mathrm{COD}) ; 63.40\left(\mathrm{~d}, \mathrm{CH} / \mathrm{COD}, \mathrm{J}_{\mathrm{CP}}=14.7 \mathrm{~Hz}\right) ; 40.13\left(\mathrm{~d}, \mathrm{~J}_{\mathrm{CP}}=5.7 \mathrm{~Hz}, \underline{\mathrm{CH}}_{2} \mathrm{Ph}\right) ; 36.61\left(\mathrm{~d}, \mathrm{~J}_{\mathrm{CP}}=\right.$ $3 \mathrm{~Hz}, \mathrm{CH}_{2} / \mathrm{COD}$ ); 31.1 (s, $\underline{\mathrm{CH}}_{2}-\mathrm{Cp}$ ); 28.25 (s, $\mathrm{CH}_{2} / \mathrm{COD}$ ). ${ }^{31} \mathrm{P}$ NMR (500 MHz, $\mathrm{CDCl}_{3}$ ) $\delta(\mathrm{ppm}):-9.00 . \mathrm{MS}\left(\mathrm{DCI}, \mathrm{NH}_{3}\right): \mathrm{m} / \mathrm{z}: 843\left(M+\mathrm{H}^{+}, 2 \%\right) ; 807\left(M-\mathrm{Cl}^{-}, 28 \%\right)$.

General procedure for asymmetric hydrogenation: in a glove box, a solution of $6.4 \times 10^{-3}$ mmol of catalyst, $3.2 \times 10^{-2} \mathrm{mmol}$ of additives (5 equiv.) and $3.2 \mathrm{mmol}$ of substrate (500 equiv.) in $2 \mathrm{~mL}$ of the desired solvent was transferred into a $5 \mathrm{~mL}$ glass ampoule which was then placed into a stainless steel autoclave. The reaction vessel was pressurized to the required $\mathrm{H}_{2}$ pressure and stirred with a magnetic bar for the desired time at controlled temperature $( \pm 2$ ${ }^{\circ} \mathrm{C}$ ). The reaction was stopped by release of pressure and quenching of the solution with $\mathrm{CH}_{2} \mathrm{Cl}_{2}$ at room temperature. The crude materials were obtained by evaporation of the solvent on rotavapor. The product was finally analysed by chiral GC (Supelco BETA DEX ${ }^{\mathrm{TM}}$ 225). 


\section{Acknowledgements}

We are grateful to the CNRS, the CNR, and the European Union (HYDROCHEM

RTN, contract HPRN-CT-2002-00176) for funding.

\section{References}

[1] a) Comprehensive Asymmetric Catalysis Vols. 1-3 (Eds.: E. N. Jacobsen, A. Pfalz, H. Yamamoto), Springer, Berlin, 1999. (b) Catalytic Asymmetric Synthesis (Ed.: I. Ojima), Wiley-VCH, New York, 2000.

[2] V. Fehring, R. Selke, Angew. Chem. Int. Ed. 1998, 37, 1827.

[3] For recent reviews on asymmetric hydrogenation: (a) H.-U. Blaser, C. Malan, B. Pugin, F. Spindler, H. Steiner, M. Studer, Adv. Synth. Catal. 2003, 345, 103. (b) W. Tang, X. Zhang, Chem. Rev. 2003, 103, 3029. (c) K. V. L. Crépy, T. Imamoto, Adv. Synth. Catal. 2003, 345, 79 .

[4] (a) T. Ohkuma, H. Ooka, S. Hashiguchi, T. Ikariya, R. Noyori, J. Am. Chem. Soc. 1995, 117, 2675.(b) R. Noyori, T. Ohkuma, Angew. Chem. Int. Ed. 2001, 40, 40. (c) R. Noyori, Angew. Chem. Int. Ed., 2002, 41, 2008.(d) T. Ohkuma, C. A. Sandoval, R. Srinivasan, Q. Lin, Y. Wie, K. Muniz, R. Noyori, J. Am. Chem. Soc. 2005, 127, 8288.

[5] (a) M. J. Burk, W. Hems, D. Herzberg, C. Malan, A. Zanotti-Gerosa, Org. Lett. 2000, 2, 4173. (b) J. P. Henschke, M. J. Burk, C. J. Malan, D. Herzberg, J. A. Peterson, A. J. Wildsmith, C. J. Cobley, G. Casy, Adv. Synth. Catal. 2003, 345, 300. (c) J.-H. Xie, L.X. Wang, Y. Fu, S.-F. Zhu, B.-M. Fan, H.-F. Duan, Q.-L. Zhou, J. Am. Chem. Soc. 2003, 125, 4404. (d) J. Wu, J.-X. Ji, R. Guo, C.-H. Yeung, A. S. C. Chan, Chem. Eur. J. 2003, 9, 2963. (e) X. Li, W. Chen, W. Hems, F. King, J. Xiao, Org. Lett. 2003, 5, 4559. (f) D. G. Genov, Angew. Chem. Int. Ed., 2004, 43, 2816. (g) A. Hu, H. L. Ngo, W. Lin, Org. Lett. 2004, 6, 2937. (h) Q. Jing, X. Zhang, J. Sun, K. Ding, Adv. Synth. Catal. 2005, 347, 1193. (i) S. Burk, G. Francio, W; Leitner, Chem. Comm. 2005, 3460. (j) K. Mikami, K. Wakabayashi, K. Aikawa, Org. Lett. 2006, 8, 1517.

[6] Cobalt: R. ter Halle, A. Bréhéret, E. Schulz, C. Pinel, M. Lemaire, Tetrahedron: Asymmetry 1997, 8, 2101.

[7] Rhodium: (a) S. Toros, B. Heil, L. Kollar, L. Marko, J. Organomet. Chem. 1980, 197, 85. (b) J. Bakos, I. Toth, B. Heil, G. Szalontai, L. Parkanyi, V. Fülop, J. Organomet. Chem. 1989, 370, 263. (c) Q. Jiang, Y. Jiang, D. Xiao, P. Cao, X. Zhang, Angew. Chem. Int. Ed., 1998, 37, 1100. (d) Y. Kuroki, Y. Sakamaki, K. Iseki, Org. Lett. 2001, 3, 457. 
[8] Iridium: (a) X. Zhang, T. Taketomi, T. Yoshizumi, H. Kumobayashi, S. Akutagawa, K. Mashima, H. Takaya, J. Am. Chem. Soc. 1993, 115, 3318. (b) A. Ferrand, M. Bruno, M. L. Tommasino, M. Lemaire, Tetrahedron: Asymmetry 2002, 13, 1379. (c) C. Maillet, T. Praveen, P. Janvier, S. Minguet, M. Evain, C. Saluzzo, M. L. Tommasino, B. Bujoli, J. Org. Chem. 2002, 67, 8191. (d) L. Dahlenburg, R. Götz, Eur. J. Inorg. Chem., 2004, 888.

[9] L Routaboul, S. Vincendeau, J.-C. Daran, E. Manoury, Tetrahedron Asym. 2005, 16, 2685.

[10] For the synthesis of enantiomerically pure synthetic intermediates (R) or (S) (2diphenylthiophosphinoferrocenyl)-methanol, see: N. Mateus, L. Routaboul, J.-C. Daran, E. Manoury, J. Organomet. Chem. 2006, 691, 2297.

[11] (a) R Malacea, E. Manoury, L. Routaboul, J.-C. Daran, R. Poli, J. P. Dunne, A. C. Withwood, C. Godard, S. B. Duckett, Eur. J. Inorg. Chem. 2006, 1803. (b) R Malacea, J.-C. Daran, S. B. Duckett, J. P. Dunne, E. Manoury, R. Poli, A. C. Withwood, Dalton Trans., 2006, 3350.

[12] For recent review of halide effects in catalysis: K. Fagnou, M. Lautens, Angew. Chem. Int. Ed. 2002, 41, 26.

[13] For recent successfull use of $I_{2}$ in transition metal-based catalysis: (a) W.-B. Wang, S.M. Lu, P.-Y. Yang, X.-W. Hen, Y.-G. Zhou, J. Am. Chem. Soc. 2003, 125, 10536. (b) Xiao, D.; Zhang, X. Angew. Chem. Int. Ed. 2001, 40, 3425.

[14] (a) M. Kitamura, S. Okata, S. Suga, R. Noyori, J. Am. Chem. Soc. 1989, 111, 4028. (b) D. Guillaneux, S.-H. Zhao, O. Samuel, D. Rainford, H. B. Kagan , J. Am. Chem. Soc. 1994, 116, 9430. (c) C. Girard, H. B. Kagan, Angew. Chem. Int. Ed. 1998, 37, 2922. (d) D. G. Blackmond, Acc. Chem. Res. 2000, 33, 402. 
Table 1. Influence of the additives on the hydrogenation of acetophenone in isopropanol ${ }^{[\mathrm{a}]}$

\begin{tabular}{|c|c|c|c|c|c|}
\hline run & catalysts & Additive & Time (h) & Conv.(\%) ${ }^{[b]}$ & TOF $\left(h^{-1}\right)^{[c]}$ \\
\hline 1 & 2-Et & None & 5 & 0 & 0 \\
\hline 2 & 2-Et & KI & 5 & 0 & 0 \\
\hline 3 & 2-Et & $\mathrm{I}_{2}$ & 5 & 2 & 1 \\
\hline 4 & 2-Et & $\mathrm{NaOMe}$ & 5 & $>99$ & $>99$ \\
\hline 5 & 2-Et & $\mathrm{KO} t \mathrm{Bu}$ & 5 & $>99$ & $>99$ \\
\hline 6 & 2-Et & $\mathrm{KOH}$ & 5 & $>99$ & $>99$ \\
\hline 7 & 2-Et & $\mathrm{NEt}_{3}$ & 5 & 0 & 0 \\
\hline $8^{[\mathrm{d}]}$ & 2-Et & $\mathrm{NaOMe}$ & 5 & 61 & 183 \\
\hline 9 & 2-Ph & $\mathrm{NaOMe}$ & 5 & $>99$ & $>99$ \\
\hline 10 & $2-t \mathrm{Bu}$ & $\mathrm{NaOMe}$ & $5^{[\mathrm{e}]}$ & $>99$ & $>99$ \\
\hline 11 & 2-Bz & $\mathrm{NaOMe}$ & 5 & $>99$ & $>99$ \\
\hline $\begin{array}{l}\text { a] React } \\
\text { nmol ; } \\
\text { sopropa } \\
\text { henyle }\end{array}$ & \multicolumn{5}{|c|}{$\begin{array}{l}\text { conditions: racemic catalyst, } 6.4 \times 10^{-3} \mathrm{mmol} \text {; additive, } 3.2 \times 10^{-2} \\
\text { ophenone, } 3.2 \mathrm{mmol} \text {; }(1 / 5 / 500) \text { under } 30 \text { bars at } 27^{\circ} \mathrm{C} \text { in } 2 \mathrm{~mL} \text { of } \\
\text { [b] Conversions determined by GC; } 100 \% \text { selectivity in }(\mathrm{R} / \mathrm{S})-1- \\
-1 \text {-ol. }{ }^{[c]} \text { Global turnover frequency. [d] Amount of acetophenone } \\
9.6 \mathrm{mmol}(\mathrm{S} / \mathrm{C} \text { ratio }=1500) \text {. }{ }^{[\mathrm{e}]} \text { The conversion was } 91 \% \text { after } 2 \mathrm{~h} \text {. }\end{array}$} \\
\hline
\end{tabular}


Table 2. Influence of the solvent and additives on the hydrogenation of acetophenone. ${ }^{[a]}$

\begin{tabular}{|c|c|c|c|c|c|c|}
\hline Run & catalysts & Additive & Solvent & Time (h) & Conv.(\% $\%)^{[b]}$ & $\operatorname{TOF}\left(\mathrm{h}^{-1}\right)^{[\mathrm{c}]}$ \\
\hline 12 & 2-Ph & $\mathrm{NaOMe}$ & $\mathrm{MeOH}$ & 2 & 68 & 170 \\
\hline 13 & 2-Ph & $\mathrm{NaOMe}$ & EtOH & 2 & 16 & 40 \\
\hline 14 & 2-Ph & $\mathrm{NaOMe}$ & $i \mathrm{PrOH}$ & 2 & $>99$ & $>247$ \\
\hline 15 & 2-Et & $\mathrm{NaOMe}$ & $i \mathrm{PrOH}$ & 2 & 94 & 234 \\
\hline 16 & 2-Et & $\mathrm{NaOMe}$ & $t-\mathrm{BuOH}$ & 2 & 1 & 2 \\
\hline $17^{\text {[d] }}$ & 2-Et & $\mathrm{NaOMe}$ & $i \mathrm{PrOH}$ & 2 & 1 & 2 \\
\hline 18 & 2-Et & $\mathrm{NaOMe}$ & Toluene & 5 & 44 & 44 \\
\hline 19 & 2-Et & $\mathrm{KO} t \mathrm{Bu}$ & Toluene & 5 & 94 & 94 \\
\hline 20 & 2-Et & $\mathrm{NaOMe}$ & $\mathrm{CH}_{3} \mathrm{CN}$ & 5 & 58 & 58 \\
\hline 21 & 2-Et & $\mathrm{KO} t \mathrm{Bu}$ & $\mathrm{CH}_{3} \mathrm{CN}$ & 5 & 52 & 52 \\
\hline 22 & 2-Et & $\mathrm{NaOMe}$ & $\mathrm{CH}_{2} \mathrm{Cl}_{2}$ & 5 & 0 & 0 \\
\hline 23 & 2-Et & $\mathrm{NaOMe}$ & THF & 5 & 1 & 1 \\
\hline \multicolumn{7}{|c|}{$\begin{array}{l}\text { [a] Reaction conditions: racemic catalyst, } 6.4 \times 10^{-3} \mathrm{mmol} \text {; additive, } 3.2 \times 10^{-2} \mathrm{mmol} \text {; } \\
\text { acetophenone, } 3.2 \mathrm{mmol} \text {; }(1 / 5 / 500) \text { under } 30 \text { bars at room temperature in } 2 \mathrm{~mL} \text { of solvent. }{ }^{[b]} \\
\text { Conversions determined by GC; } 100 \% \text { selectivity in }(\mathrm{R} / \mathrm{S})-1 \text {-phenylethan-1-ol. }{ }^{[\mathrm{c}]} \text { Global } \\
\text { turnover frequency }{ }^{[\mathrm{d}]} \text { Identical conditions as in }{ }^{[\mathrm{a}]} \text { except } \mathrm{P}\left(\mathrm{H}_{2}\right)=2 \text { bars. }\end{array}$} \\
\hline
\end{tabular}


Table 3. Asymmetric hydrogenation of alkylarylketones ${ }^{[a]}$

\begin{tabular}{|c|c|c|c|c|c|}
\hline Run & Catalyst & $\mathrm{X}$ (position) & $t(h)$ & conv. $(\%)^{[b]}$ & ee $(\%)^{[b]}$ \\
\hline 24 & (S)-2-Et & $\mathrm{H}$ & 2 & 94 & 68 \\
\hline 25 & (S)-2-Ph & $\mathrm{H}$ & 2 & $>99$ & 43 \\
\hline 26 & $(\mathrm{~S})-2-t \mathrm{Bu}$ & $\mathrm{H}$ & 2 & 92 & 59 \\
\hline 27 & (S)-2-Bz & $\mathrm{H}$ & 2 & 95 & 77 \\
\hline 28 & (S)-2-Et & $\mathrm{Cl}(2)$ & 2 & 96 & 51 \\
\hline 29 & (S)-2-Ph & $\mathrm{Cl}(2)$ & 2 & $>99$ & 33 \\
\hline 30 & $(\mathrm{~S})-2-\mathrm{tBu}$ & $\mathrm{Cl}(2)$ & 2 & 98 & 30 \\
\hline 31 & (S)-2-Bz & $\mathrm{Cl}(2)$ & 2 & $>99$ & 56 \\
\hline 32 & (S)-2-Et & $\mathrm{F}(2)$ & 2 & 71 & 37 \\
\hline 33 & (S)-2-Ph & $\mathrm{F}(2)$ & 2 & $>99$ & 11 \\
\hline 34 & $(\mathrm{~S})-2-t \mathrm{Bu}$ & $\mathrm{F}(2)$ & 2 & 47 & 17 \\
\hline 35 & (S)-2-Bz & $\mathrm{F}(2)$ & 2 & 82 & 47 \\
\hline 36 & (S)-2-Et & $\operatorname{Me}(3)$ & 2 & 18 & 66 \\
\hline 37 & (S)-2-Ph & $\operatorname{Me}(3)$ & 2 & 94 & 41 \\
\hline 38 & $(\mathrm{~S})-2-t \mathrm{Bu}$ & $\operatorname{Me}(3)$ & 2 & 20 & 55 \\
\hline 39 & (S)-2-Bz & $\operatorname{Me}(3)$ & 2 & 31 & 72 \\
\hline 40 & (S)-2-Et & $\operatorname{Me}(4)$ & 2 & 85 & 67 \\
\hline 41 & (S)-2-Ph & $\operatorname{Me}(4)$ & 2 & 97 & 72 \\
\hline 42 & $(\mathrm{~S})-2-t \mathrm{Bu}$ & $\operatorname{Me}(4)$ & 2 & 72 & 68 \\
\hline 43 & (S)-2-Bz & $\operatorname{Me}(4)$ & 2 & 81 & 73 \\
\hline 44 & (S)-2-Et & $\mathrm{Cl}(4)$ & 2 & 92 & 61 \\
\hline 45 & (S)-2-Ph & $\mathrm{Cl}(4)$ & 2 & $>99$ & 31 \\
\hline 46 & $(\mathrm{~S})-2-t \mathrm{Bu}$ & $\mathrm{Cl}(4)$ & 2 & 68 & 55 \\
\hline 47 & (S)-2-Bz & $\mathrm{Cl}(4)$ & 2 & 88 & 76 \\
\hline 48 & (S)-2-Et & $\mathrm{F}(4)$ & 2 & 16 & 61 \\
\hline 49 & (S)-2-Ph & $\mathrm{F}(4)$ & 2 & $>99$ & 74 \\
\hline 50 & $(\mathrm{~S})-2-t \mathrm{Bu}$ & $\mathrm{F}(4)$ & 2 & 72 & 57 \\
\hline 51 & (S)-2-Bz & $\mathrm{F}(4)$ & 2 & 64 & 75 \\
\hline
\end{tabular}

${ }^{[a]}$ Reaction conditions: catalyst, $6.4 \times 10^{-3} \mathrm{mmol}$; NaOMe, $3.2 \times 10^{-2} \mathrm{mmol}$; substrate, $3.2 \mathrm{mmol}(1 / 5 / 500)$ at $27^{\circ} \mathrm{C} .{ }^{[b]}$ Conversion and ee determined by GC. In each case, the absolute configuration configuration of product is $\mathrm{S}$ (assigned by comparison of rotation sign in literature data) 
Table 4. Asymmetric hydrogenation of alkylarylketones ${ }^{[a]}$

\begin{tabular}{|c|c|c|c|c|c|}
\hline Run & Catalyst & $\bar{X}$ & t (h) & $\operatorname{conv} .(\%)^{[b]}$ & ee $(\%)^{[b]}$ \\
\hline 52 & (S)-2-Et & $\mathrm{H}$ & 8 & $>99$ & 78 \\
\hline 53 & (S)-2-Bz & $\mathrm{H}$ & 8 & 99 & 87 \\
\hline 54 & (S)-2-Et & $\mathrm{Me}$ & 8 & 86 & 93 \\
\hline 55 & (S)-2 -Bz & $\mathrm{Me}$ & 8 & 84 & 93 \\
\hline 56 & (S)-2-Et & $\mathrm{F}$ & 8 & $>99$ & $>99$ \\
\hline 57 & (S)-2-Bz & $\mathrm{F}$ & 8 & 96 & $>99$ \\
\hline
\end{tabular}

[a] Reaction conditions: catalyst, $6.4 \times 10^{-3} \mathrm{mmol}$; NaOMe, $3.2 \times 10^{-2} \mathrm{mmol}$; substrate, $3.2 \mathrm{mmol}(1 / 5 / 500)$ at $10^{\circ} \mathrm{C}$. ${ }^{[b]}$ Conversion and ee determined by GC. In each case, the absolute configuration configuration of product is $\mathrm{S}$ (assigned by comparison of rotation sign in literature data). 

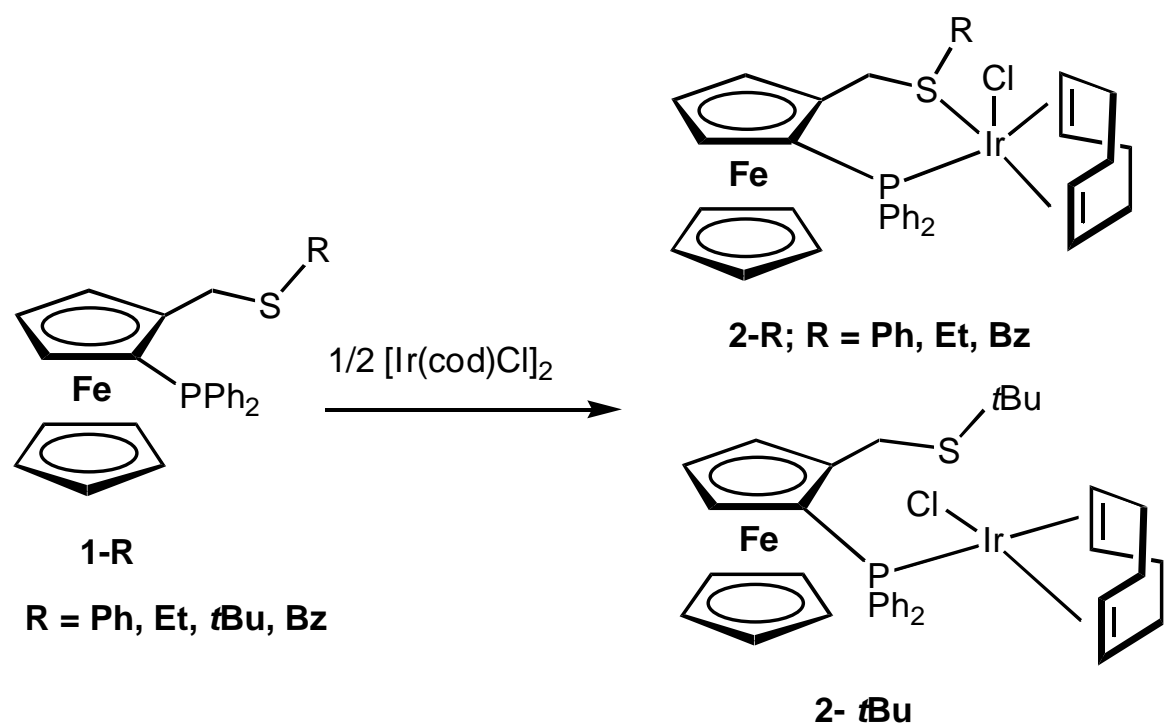

Scheme 1 Synthesis of complexes 2. 
Communication

Highly efficient asymmetric hydrogenation of alkyl aryl ketones catalyzed by iridium complexes with chiral planar ferrocenyl phosphino-thioether ligands

Erwan Le Roux, ${ }^{a}$ Raluca Malacea, ${ }^{\mathrm{b}}$ Eric Manoury, ${ }^{\mathrm{b} \dagger}$ Rinaldo Poli, ${ }^{\mathrm{b}}$ Luca Gonsalvi, ${ }^{\mathrm{a}}$ Maurizio Peruzzini $^{\mathrm{a}^{*}}$

${ }^{a}$ Consiglio Nazionale delle Ricerche, Istituto di Chimica dei Composti Organometallici(ICCOM-CNR), Via Madonna del Piano, 50019 Sesto Fiorentino (Firenze), Italy; e-mail: mperuzzini@iccom.cnr.it

${ }^{\mathrm{b}}$ Centre National de la Recherche Scientifique, Laboratoire de Chimie de Coordination (CNRS-LCC),205, route de Narbonne, 31077 Toulouse Cedex 4,France; e-mail: manoury@lcc-toulouse.fr

\section{KEYWORDS}

alkyl aryl ketones; asymmetric catalysis; ferrocene ligands; hydrogenation;

iridium; P,S ligands

\section{ABSTRACT}

Iridium complexes of planar-chiral ferrocenyl phosphine-thioether ligands were tested in the hydrogenation of simple ketones. Conditions optimization led to a highly active catalytic system with turnover numbers up to 915 and turnover frequencies up to ca. $250 \mathrm{~h}^{-1}$. Furthermore, very high enantioselectivities (up to $>99 \%$ ) together with complete conversions were obtained for the asymmetric hydrogenation of various acetophenones at $10{ }^{\circ} \mathrm{C}$. 


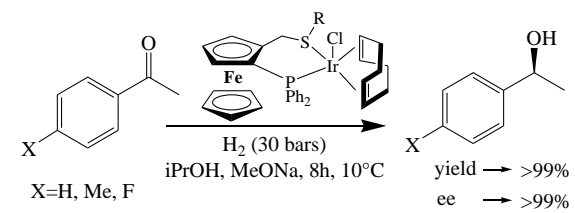

